\title{
The seed bank in an old-growth, temperate deciduous forest
}

\author{
Sara Leckie, Mark Vellend, Graham Bell, Marcia J. Waterway, and Martin J. \\ Lechowicz
}

\begin{abstract}
We assessed the size and composition of the seed bank in 31 plots representing a range of habitats within an old-growth, temperate deciduous forest at Mont St. Hilaire, Québec, Canada. We identified 49 taxa in the seed bank, with an average of 40 species $\cdot \mathrm{m}^{-2}$ and a median density of 1218 seeds $\cdot \mathrm{m}^{-2}$. The most frequent seeds were species of Carex and Rubus, Diervilla lonicera, and Eupatorium rugosum, while seeds of Carex were the most numerous overall. Of the 12 species in the seed bank not found in the forest, 11 were found growing on the developed landscape surrounding this $10-\mathrm{km}^{2}$ forest fragment. These nonforest species were numerically only a minor component of the forest seed bank. Vernal herbs were not in the seed bank, and there were only a few tree species. Variation in seed bank richness among habitats was correlated positively with canopy cover, soil moisture, and soil nutrients, but not with the seed bank density or total number of species in the aboveground vegetation. Seed bank density increased with plot soil moisture. Woody species predominated in the seed bank of plots with richer soils, deeper litter, and more closed canopies. Herbaceous species predominated in the seed bank of plots with more open canopies, more mesic water regimes, and greater species richness in the aboveground vegetation. Contrary to earlier results suggesting forest seed banks primarily include shade-intolerant species associated with canopy disturbance or secondary succession, the seed bank in this old-growth, primary forest contains many shade-tolerant forest species.
\end{abstract}

Key words: seed bank, old-growth forest, primary forest, temperate deciduous forest, habitat diversity, seed dispersal.

Résumé : Les auteurs ont évalué la dimension et la composition de la banque de graines de 31 parcelles représentant une gamme d'habitats à l'intérieur d'une forêt décidue âgée située au Mont St-Hilaire, Québec, Canada. Ils ont identifié 49 taxons dans la banque de graines, avec une moyenne de 40 espèces $\cdot \mathrm{m}^{-2}$ et une densité médiane de 1218 graines $\cdot \mathrm{m}^{-2}$. Les graines les plus fréquentes sont celles d'espèces de Carex et de Rubus, du Diervilla lonicera, et de l'Eupatorium rugosum, alors que les graines de Carex sont les plus nombreuses dans l'ensemble. Sur les 12 espèces de graines de la banque, absentes dans la forêt, on en retrouve 11 poussant sur les paysages développés qui entourrent ce fragment forestier de $10 \mathrm{~km}^{2}$. En nombres, ces espèces non-forestières ne constituent qu'une faible composante de la banque de graine de cette forêt. Les herbacées printanières ne se retrouvent pas dans la banque de graines et on n'observe que quelques espèces d'arbres. La variation de la richesse de la banque de graines varie selon les habitats et montre une corrélation positive avec l'ouverture de la canopée, l'humidité du sol et les nutriments du sol, mais non avec la densité des banques de graines ou le nombre total d'espèces dans la végétation épigée. La densité des banques de graines augmente avec l'humidité du sol des parcelles. Les espèces ligneuses sont dominantes dans la banque de graines des parcelles ayant un sol plus riche, une litière plus épaisse et des canopées plus fermées. Les espèces herbacées dominent dans la banque de graines des parcelles ayant des canopées plus ouvertes, des régimes hydriques plus mésiques, et une plus grande richesse en espèces dans la végétation épigée. Contrairement à des résultats antécédents qui suggéraient que les banques de graines des forêts incluent surtout des espèces intolérantes à l'ombre, associées avec une perturbation de la canopée ou à la succession secondaire, la banque de graine de cette forêt primaire âgée contient plusieurs espèces forestières tolérant l'ombre.

Mots clés : banque de graines, forêt âgée, forêt primaire, forêt décidue tempérée, diversité des habitats, dispersion des graines.

[Traduit par la Rédaction]

Received February 5, 1999.

S. Leckie, M. Vellend, G. Bell, and M.J. Lechowicz. ${ }^{1}$ Department of Biology, McGill University, 1205 Dr. Penfield Avenue, Montréal, QC H3A 1B1, Canada.

M.J. Waterway. Department of Plant Science, Macdonald Campus of McGill University, 21,111 Lakeshore Road, Ste-Anne-deBellevue, QC H9X 3V9, Canada.

${ }^{1}$ Author to whom all correspondence should be addressed (e-mail: martin@bio1.lan.mcgill.ca). 


\section{Introduction}

Seed dynamics play an important role in structuring and maintaining plant communities. Seeds sustain populations during temporarily unfavorable conditions, allow establishment in new areas, and can introduce novel genotypes to populations (Cavers 1983; Fenner 1985). Seed banks, in particular, are important in maintaining species and genetic diversity in communities and in allowing species to persist through disturbance or adverse conditions (Thompson 1992; Rees 1996). The existence of soil seed banks has been documented in many different plant communities (Fenner 1985; Leck et al. 1989; Thompson 1992; Thompson et al. 1997; Baskin and Baskin 1998). Most past studies of seed banks have concerned arable lands and successional fields (see literature compiled in Thompson et al. 1997) where seed bank composition reflects historical land use and includes many weedy invaders and colonizers (Thompson and Grime 1979; Thompson 1992). While fewer investigations of forest seed banks have been made, it is clear that seed banks are important in forest regeneration and recovery after disturbance (Nakagoshi 1985; Pickett and McDonnell 1989; Mladenoff 1990; Hughes and Fahey 1991; Houle 1994; Peterson and Pickett 1995; Peterson and Carson 1996; JankowskaBłaszczuk and Grubb 1997; Jankowska-Błaszczuk et al. 1998). Studies of seed banks in managed and secondary forests rather than primary, old-growth forests have predominated. We know relatively little about the ecological significance of seed banks in primeval forest systems. If we aim to understand the functional ecology of forest seed banks, old-growth forests with little modification by humans, fewer edge effects, and fewer nonnative species must be given more attention (Pickett and McDonnell 1989; Matlack and Good 1990).

In this study, we characterized the soil seed bank in a tract of old-growth, temperate deciduous forest that is over 1000 ha in extent but surrounded by agricultural and developed land near the perimeter of greater Montréal, Québec. We sampled many diverse habitats within this tract of forest. With this approach, we were able to explore relationships among the existing vegetation, seed bank composition, and environmental variables within a single, continuous, oldgrowth forest ecosystem. Our approach is in contrast with studies that compared sites separated by modified landscapes, compared sites of different age since last disturbance (often human disturbance, such as clear-cutting), attempted to characterize a whole forest by selecting one "representative" area, or that aimed to elucidate patterns from studies in different geographical areas. Our general objectives were (i) to determine the size and composition of the seed bank in a broad range of habitats within this large fragment of oldgrowth forest and (ii) to describe the relationships among the seed bank, existing vegetation, and environmental factors within the forest. We focused our attention on the following generalizations or expectations: $(i)$ the seed bank in this oldgrowth primary forest will have relatively low seed and species numbers compared with seed banks reported in midsuccessional secondary forests (Thompson 1992; Peterson and Carson 1996), (ii) the seed bank will vary with environmental differences from place to place within the forest (Pickett and McDonnell 1989; Beatty 1991; Ashtonet al.
1998), (iii) seeds of shade-intolerant forest herbs dependent on canopy disturbance will predominate in the seed bank of the forest as a whole (Pickett and McDonnell 1989; Thompson 1992; Jankowska-BŁaszczuk and Grubb 1997), (iv) seeds of vernal herbs and trees will be underrepresented in the seed bank of the forest as a whole (Pickett and McDonnell 1989; Thompson 1992; Jankowska-BŁaszczuk and Grubb 1997), and (v) seeds of weedy species from the surrounding landscape will be overrepresented in the seed bank of this remnant of once more extensive forests.

\section{Materials and methods}

\section{Study area}

This study was undertaken in an old-growth temperate deciduous forest on Mont St. Hilaire in southwestern Québec, Canada $\left(45^{\circ} 31^{\prime} \mathrm{N}, 73^{\circ} 08^{\prime} \mathrm{W}\right)$. Mont St. Hilaire is one of the eight rugged and physiographically diverse Monteregian Hills (Feininger and Goodacre 1995) in the St. Lawrence Lowlands (Poole et al. 1976), an otherwise flat landscape dominated by farmland and land developed for housing and industry. This forest, which covers all but the lowermost flanks of Mont St. Hilaire, is approximately $10 \mathrm{~km}^{2}$ in extent and by far the largest remnant of primeval forests in the region. The site has had only a few human-caused disturbances since Europeans first settled the region in the early 17th century: establishment of a sparse network of hiking trails, some localized maple sugar production in the mid-19th century, selective cutting of trees in a few restricted localities early in the 20th century, and localized fires of varying extent and intensity in the past 50 years. While most of the forest is essentially undisturbed by people, it has been subjected to repeated damage by glaze ice storms that are frequent at the northern edge of the deciduous forest biome in North America (Melancon and Lechowicz 1987; Hooper 1999). Though showing signs of past ice damage, many of the trees exceed 150 years in age and a few are over 450 years old (Cook 1971). There is considerable diversity in forest composition within the site as a function of drainage and aspect (Maycock 1961; Enright and Lewis 1985). A recent survey of the entire mountain in contiguous 1/4-ha quadrats found the most frequent tree species to be Acer saccharum (95\% frequency), Acer pensylvanicum (77\%), Fagus grandifolia (75\%), Fraxinus americana (73\%), Quercus rubra (64\%), Ostrya virginiana (57\%), Tilia americana (52\%), Betula papyrifera $(42 \%)$, Acer spicatum (39\%), Prunus virginiana (29\%), and Betula alleghaniensis (26\%). Mont St. Hilaire has a particularly rich herbaceous flora (Marie-Victorin 1913; Raymond 1950; Maycock 1961). Several species occur there that are rare or endangered in Quebec, including Adlumia fungosa, Allium tricoccum, Asclepias exaltata, Carex backii, C. digitalis, C. platyphylla, Desmodium nudiflorum, Dryopteris clintoniana, Galearis spectabilis, Lysimachia hybrida, Panax quinquefolius, Phegopteris hexagonoptera, Platanthera macrophylla, Staphylea trifolia, and Viola rostrata (Lavoie 1992).

Thirty-one study plots, each $50 \times 25 \mathrm{~m}$, were established with the aim of covering a wide range of environmental conditions along gradients of slope, aspect, moisture regime, canopy cover, and species composition (Table 1). They can be generally characterized as Acer saccharum - Fagus grandifolia forests on ridge tops and slopes $(1,9,17,27,38,44,45)$, streamsides and ephemeral ponds in Acer saccharum - Fagus grandifolia forests (11, 18, 25, 31), Fagus grandifolia - Tsuga canadensis forests $(26,29)$, Acer saccharum - Tsuga canadensis forests (19, 20, 21), Tsuga candensis - Pinus strobus forests (50), Betula alleghaniensis Tsuga canadensis forests $(6,36)$, Quercus rubra - Acer saccharum forests $(13,22,33)$, mixed Pinus-hardwood forests on drier sites $(10,14,16,34)$, and diverse forests on wet sites $(3,28,37,39,46)$. The complete floristic composition for all plots can be provided on 
request to the authors. These plots are part of ongoing ecological studies on the diversity and environmental relationships of Carex species (Bell et al. 2000). All the plots were located in the interior of the forest in areas little frequented by people.

\section{Soil samples}

Soil samples were collected during May 1997. At that time, seeds released the previous summer would have had a natural cold stratification, seeds from the 1997 season would not yet have been released, and there would not yet have been an opportunity for seeds to germinate that spring. There is some disagreement in the literature on the best time to sample seed banks (Baskin and Baskin 1998); we recognize that we are sampling both persistent and transient seed banks. Soil samples were collected along a central transect running the length of each plot, at points 12.5, 20.5, 28.5 , and $37.5 \mathrm{~m}$ along the $50-\mathrm{m}$ axis of the plot. At each point, we collected soil to a depth of $10 \mathrm{~cm}$, in a circle with a $5.6-\mathrm{cm}$ radius, to yield a total soil volume of $2 \mathrm{~L}$, and a total soil surface area of $0.04 \mathrm{~m}^{2}$ per plot. Leaf litter over the soil was also collected, and seeds present were shaken out and added to the soil sample. In previous studies, the majority of seeds have generally been found in the litter-fermentation-humus layers, and in the top $5 \mathrm{~cm}$ of soil, with fewer seeds found down to $10 \mathrm{~cm}$ (Kellman 1970; Graber and Thompson 1978; Piroznikov 1983; Pratt et al. 1984; Kramer and Johnson 1987). The soil samples were briefly refrigerated, but not frozen.

\section{Seedling emergence technique}

The density and composition of the seed bank were determined by observing seedling emergence. In early June, the leaves, rocks, and twigs in each sample were removed, and the remaining soil from each study plot was mixed thoroughly. The soil samples were divided in half and spread out in two plastic trays $(35 \times 70 \mathrm{~cm})$ to a depth of $1 \mathrm{~cm}$ atop $3 \mathrm{~cm}$ of sand. Each tray from each plot was assigned a random position in one of two replicate blocks. The trays were placed outside the McGill University Research Centre at Mont St. Hilaire in an open frame covered by $50 \%$ shade cloth. All the trays were watered as often as needed to keep the soil moist. Three control trays containing a 1-cm layer of weed-free potting soil over $3 \mathrm{~cm}$ of sand were placed randomly in each replicate block to quantify germination of ambient seeds blown into the experimental trays. We found no significant difference in species number or density between replicate blocks, so the results were combined for all analyses. One tray of potting soil also was kept indoors, in light, and watered, to check for viable seeds; none were found. Six taxa were found in the control trays and were excluded from further analyses. Populus deltoides and P. grandidentata, which grew abundantly near where the trays were placed, accounted for almost all the seed of excluded species; $P$. grandidentata is found in the forest and may well be a component of the natural seed bank. While observing emergence does not allow for a complete assessment of the buried viable seeds, the technique is more commonly used, gives less variable results, and is appropriate for the objective of determining which seeds may germinate in the event of a disturbance (Brown 1992).

Seedling emergence in the trays was scored weekly from June through August 1997, and once again in late September. By this time no new seedlings were emerging; Graber and Thompson (1978) found that $93 \%$ of seeds from a beech-birch-maple forest germinated in the first summer. Color-coded and labeled toothpicks marked new emergent taxa in each tray, and the total number of individuals of each taxon was recorded weekly. Seedlings were removed from the trays as identifications were made. Seedling identification was facilitated using a seedling guide (Brayshaw 1959) and by transplanting individuals to be grown to maturity under greenhouse conditions.

\section{Vegetation and environmental characterization}

To record every species of vascular plant present within the $25 \times$ $50 \mathrm{~m}$ study plots, we made surveys in both the spring and late summer 1997. Each plot also was categorized as xeric, mesic, or wet, and was scored for total canopy cover, the density of subcanopy trees, and total leaf litter cover. We used these data to create a composite index of forest cover at each site (FOREST); this FOREST index was the score on axis 1 in a detrended correspondence analysis (DCA) of the presence or absence of tree species in each plot. The DCA analysis was done in CANOCO 4.0 (ter Braak and Smilauer 1998).

Additional soil samples were collected in late summer 1997 to a depth of $5 \mathrm{~cm}$ at six points along the long axis of each plot. These samples did not include the litter-fermentation-humus layers. The samples were pooled for each plot and were analyzed for six mineral nutrients $\left(\mathrm{NO}_{3}-\mathrm{N}, \mathrm{NH}_{4}-\mathrm{N}, \mathrm{PO}_{4}-\mathrm{P}, \mathrm{K}, \mathrm{Ca}, \mathrm{Mg}\right)$ as well as percent organic matter. Soil samples were kept frozen for 2 months before analysis. Percent organic matter was determined by loss on ignition at $800^{\circ} \mathrm{C}$. Nutrient extractions of air-dried and sieved $(2 \mathrm{~mm})$ soil samples and analyses of these extracts were carried out by the University of Alberta Soil Chemistry Laboratory. Exchangeable nitrate and ammonium were assayed in a $\mathrm{KCl}$ extract (Kalra and Maynard 1991); available phosphorus was assayed using an $\mathrm{NH}_{4} \mathrm{~F}-\mathrm{H}_{2} \mathrm{SO}_{4}$ extract (method 2 of Bray and Kurtz 1945); exchangeable potassium, calcium, and magnesium were determined on an $\mathrm{NH}_{4}-\mathrm{OAc}$ extract at $\mathrm{pH} 7$ (Chapman 1965).

\section{Data analysis}

We analyzed two different aspects of the seed bank: composition and properties characterizing the seed bank as a whole. Composition is simply the number of seedlings of each taxon at each plot. To characterize the seed bank as a whole at each plot, we calculated the species richness, seed density (seeds $\cdot \mathrm{m}^{-2}$ soil surface), and the proportion of taxa in categories defined by: (i) life form, (ii) status as alien or native (to North America), and (iii) potential dispersal distance (long, i.e., wind-, bird-, or mammal-dispersed; or short, i.e., ant- or self-dispersed). We calculated these same characteristic properties for the aboveground vegetation in each plot Taxa were assigned to categories based on information in Gleason and Cronquist (1991), Marie-Victorin (1995), Handel et al. (1981), Handel and Beattie (1990), and Martin et al. (1951). All nomenclature follows Gleason and Cronquist (1991). To compare the proportion of species that were alien, annual, and woody in the seed bank and in the vegetation, we conducted paired $t$-tests using SYSTAT 7.0.1 (SPSS Inc., Chicago, Ill.).

To assess variation among plots in seed bank composition, we did a detrended correspondence analysis (DCA, Jongman et al. 1995) using CANOCO (ter Braak and Smilauer 1998). DCA is an ordination method for indirect gradient analysis in which environmental variables are not included in the calculations of ordination axes, but are compared with the ordination axes following analysis (see below). DCA was preferred over methods of direct gradient analysis, because our approach to analyzing seed bank - environment relationships was largely exploratory (Økland 1996). To avoid artifacts arising through undersampling of less frequent taxa in the seed bank, only taxa that were found in three or more study plots were included in the DCA analysis. Prior to the DCA, log transformations were performed to reduce positive skew in the seed bank data and in four environmental variables: ammonium, nitrate, phosphorous, and calcium. Species-environment biplots were constructed in which arrows representing environmental variables were plotted together with species scores in the ordination diagram (ter Braak and Smilauer 1998). The biplot scores are obtained by weighted regression of environmental variables on species scores in the DCA ordination of the 24 most frequent species in the 31 study plots. The longer the arrow radiating from the centroid of the ordination, the higher the correlation between that environ- 
Table 1. Summary of environmental, vegetation, and seed bank characteristics of each study plot.

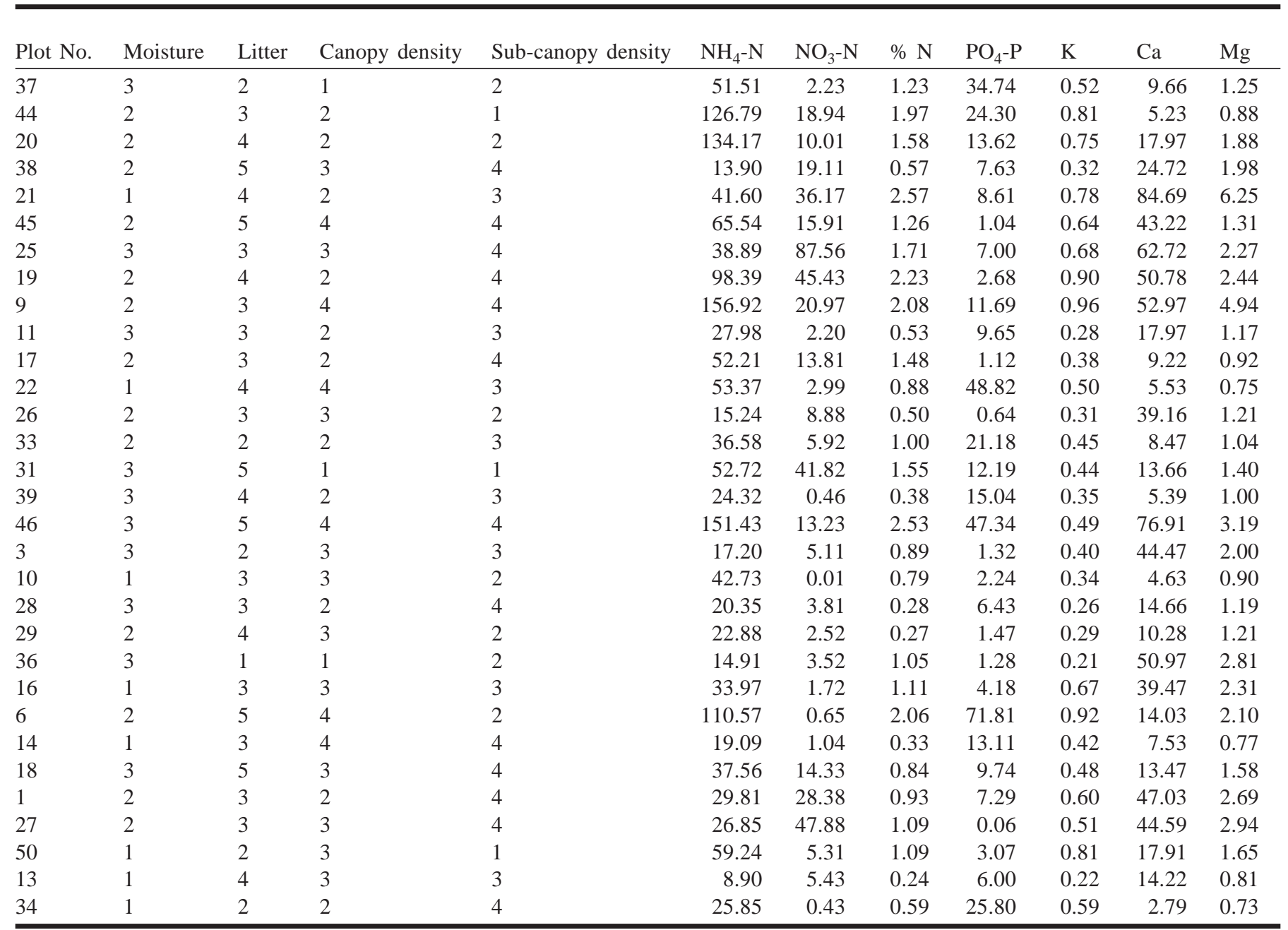

Note: Moisture regime is scored as follows: 1, xeric; 2, mesic; or 3, wet. Litter: 1, none; 2, some litter, but bare ground present; 3, thin, but almost closed (5). Subcanopy sapling layer: none (1) to dense (4). Soil nutrients: $\mathrm{NO}_{3}-\mathrm{N}$, nitrate in soil (ppm); $\mathrm{NH}_{4}-\mathrm{N}$, ammonium in soil (ppm); $\mathrm{PO}_{4}-\mathrm{P}$, Numbers of native taxa of woody taxa, herbs, and ferns and the number of alien taxa (all herbs) identified in the aboveground vegetation. Number of the number of native taxa in the seed bank at each plot.

mental variable and the ordination axes (ter Braak and Smilauer 1998).

The similarity between species composition in the seed bank and in the aboveground vegetation at each plot was assessed using Jaccard's coefficient. Values of Jaccard's coefficient range between 0 , for no species shared in common, and 1 , for complete concurrence. To test whether variation among plots in seed bank composition was related to variation among plots in tree-species composition, we conducted a Mantel test (Mantel 1967) on matrices of similarity among plots for the two data sets using RT version 2.1 (Manly 1997). Mantel tests incorporate all the variation in two (or more) multivariable data sets and provides a simple way to compare them (Legendre and Legendre 1998). A significant result would indicate that seed-bank composition can be predicted from tree-species composition. We used the Bray-Curtis distance measure for the seed bank data and the Jaccard distance for the tree data (Legendre and Legendre 1998).

We assessed the relationships between the characteristics of the seed bank and the measured environmental factors using a principal component analysis (PCA). A PCA was preferred over DCA for this analysis, because DCA was designed specifically for vegetation data, with the assumption that species distributions along environmental gradients (represented by ordination axes) are uni- modal (Jongman et al. 1995). This PCA examines correlations among the various characteristics of the seed bank, not relationships among the distributions of individual taxa in the seed bank. After the PCA axes were defined, we made a weighted regression of the environmental variables on the principal component scores for the seed bank properties.

\section{Results}

\section{Overall richness and density of the seed bank and aboveground vegetation}

A total of 2999 seedlings emerged during the trial, representing at least 49 distinct taxa (species, or genera) with a mean density of $40 \mathrm{taxa} \cdot \mathrm{m}^{-2}$ (Table 2). There were 786 unidentified seedlings in the trays, nearly all grass or sedge species. To more completely assess the number of taxa present in the seed bank, seedlings of Carex were identified to species or section whenever possible, but Carex not identified to species were lumped as Carex spp. in data analyses. The number of seed bank taxa per plot ranged from 5 to 17 with a median of 8 species, while seed densities in individ- 


\begin{tabular}{|c|c|c|c|c|c|c|c|}
\hline $\begin{array}{l}\text { No. of } \\
\text { woody taxa }\end{array}$ & $\begin{array}{l}\text { No. of } \\
\text { herb taxa }\end{array}$ & $\begin{array}{l}\text { No. of } \\
\text { fern taxa }\end{array}$ & $\begin{array}{l}\text { No. of } \\
\text { alien taxa }\end{array}$ & $\begin{array}{l}\text { No. of native } \\
\text { seed taxa }\end{array}$ & $\begin{array}{l}\text { No. of alien } \\
\text { seed taxa }\end{array}$ & $\begin{array}{l}\text { Seed density }\left(\text { seeds } \cdot \mathrm{m}^{-2} \text { ) }\right. \\
\text { for native species }\end{array}$ & $\begin{array}{l}\text { Seed density (seeds } \cdot \mathrm{m}^{-2} \text { ) } \\
\text { for alien species }\end{array}$ \\
\hline 14 & 41 & 11 & 2 & 14 & 3 & 8000 & 75 \\
\hline 14 & 19 & 4 & 1 & 13 & 1 & 2200 & 50 \\
\hline 13 & 22 & 5 & 0 & 13 & 0 & 2025 & 0 \\
\hline 8 & 32 & 5 & 1 & 12 & 2 & 875 & 50 \\
\hline 18 & 22 & 4 & 0 & 12 & 1 & 1275 & 25 \\
\hline 18 & 29 & 8 & 2 & 11 & 1 & 1175 & 25 \\
\hline 13 & 28 & 4 & 1 & 9 & 2 & 775 & 150 \\
\hline 13 & 35 & 14 & 1 & 9 & 2 & 16200 & 500 \\
\hline 12 & 25 & 6 & 0 & 9 & 1 & 2925 & 25 \\
\hline 22 & 31 & 4 & 2 & 9 & 1 & 2025 & 50 \\
\hline 20 & 47 & 11 & 1 & 9 & 0 & 700 & 0 \\
\hline 15 & 26 & 8 & 1 & 7 & 2 & 750 & 125 \\
\hline 14 & 33 & 9 & 2 & 7 & 1 & 1725 & 25 \\
\hline 15 & 12 & 3 & 0 & 7 & 1 & 750 & 25 \\
\hline 17 & 51 & 14 & 3 & 7 & 1 & 1525 & 25 \\
\hline 11 & 37 & 12 & 1 & 7 & 1 & 700 & 25 \\
\hline 16 & 39 & 9 & 1 & 7 & 1 & 11800 & 25 \\
\hline 19 & 29 & 3 & 1 & 6 & 2 & 1650 & 550 \\
\hline 12 & 37 & 12 & 1 & 6 & 1 & 2000 & 25 \\
\hline 18 & 27 & 4 & 1 & 6 & 1 & 2325 & 50 \\
\hline 13 & 55 & 10 & 4 & 6 & 1 & 450 & 25 \\
\hline 7 & 22 & 3 & 0 & 6 & 0 & 675 & 0 \\
\hline 9 & 28 & 7 & 2 & 5 & 1 & 1050 & 50 \\
\hline
\end{tabular}

continuous leaf litter; 4, ground essentially covered by leaf litter; and 5, thick, continuous leaf litter. Canopy density: essentially open (1) to completely phosphorous in soil (ppm); $\mathrm{K}$, potassium in soil (mequiv. $100 \mathrm{~g}^{-1}$ ); Ca, calcium in soil (mequiv. $100 \mathrm{~g}^{-1}$ ); $\mathrm{Mg}$, magnesium in soil (mequiv. $100 \mathrm{~g}^{-1}$ ).

native and alien taxa identified in the seed bank and the densities of native and alien seed at each study plot. The table is arranged in descending order of

ual plots ranged from 482 to 16954 seeds $\cdot \mathrm{m}^{-2}$ with a median of 1218 seeds $\cdot \mathrm{m}^{-2}$ overall (Table 1). A total of 186 species were identified in the aboveground vegetation ranging from 30 to 82 species per $25 \times 50 \mathrm{~m}$ study plot with a median of 49 (Table 1).

\section{Composition of the seed bank and aboveground vegetation}

Species that were particularly frequent in the seed bank, occurring at more than $50 \%$ of plots, included Diervilla lonicera, Eupatorium rugosum, species of Rubus, species of Carex, and other graminoid species. Seeds of the genus Carex were the most numerous overall (Table 2). Notably absent from the seed bank were vernal species, which are found in high numbers in the aboveground vegetation at Mont St. Hilaire. Species of Trillium and Uvularia, Maianthemum canadense, Streptopus roseus, Erythronium americanum, and Polygonatum pubescens were all found in more than half the study plots, but no seedlings of any of these species germinated from our soil samples. With the exception of Betula papyrifera and Tsuga canadensis, we found relatively few tree seeds in the seed bank at Mont St. Hilaire. There was a higher proportion of woody species in the seed bank than in the aboveground vegetation, but this is attributable to the many shrub species in the seed bank and the high number of herbaceous species found in the vegetation that were not present in the seed bank.

Of the 49 taxa identified in the seed bank, 12 were not found in the vegetation samples of any of the 31 plots (Table 2). Except for Carex novae-angliae, none of these 12 species are generally forest species and were likely blown or carried in from the adjacent modified landscape or from locally disturbed or marginal areas of the forest. Similarity between the seed bank composition and the vegetation at individual plots was low: values of Jaccard's coefficient of community ranged from 0 to 0.128 , with a mean of 0.058 . The percentage of species in the seed bank that were also in the aboveground vegetation at each plot ranged from 0 to $83 \%$ and averaged $38 \%$. We did find a significant positive relationship between the Bray-Curtis distances among plots based on the seed bank data and Jaccard distances based on the tree data (Mantel test: $F=19.64, P=0.0002$ ), though 
Table 2. Summary of frequency, maximum density, and plant characteristics for each taxon in the seed bank.

\begin{tabular}{|c|c|c|c|c|c|c|c|c|c|c|}
\hline Acronym & Family & Genus & Species & $\begin{array}{l}\text { Total no. } \\
\text { of sites }\end{array}$ & $\begin{array}{l}\text { Maximum density } \\
\left(\text { seeds } \cdot \mathrm{m}^{-2}\right)\end{array}$ & Woody & Monocotyledon & $\begin{array}{l}\text { Annual/ } \\
\text { biennial }\end{array}$ & $\begin{array}{l}\text { Alien/ } \\
\text { weedy }\end{array}$ & $\begin{array}{l}\text { Long-distance } \\
\text { dispersal }\end{array}$ \\
\hline RUBSPP & Rosaceae & Rubus & spp. & 28 & 1650 & 1 & 0 & 0 & 0 & 1 \\
\hline CARSPP & Cyperaceae & Carex & spp.*† & 26 & 1975 & 0 & 1 & 0 & 0 & 0 \\
\hline DIELON & Caprifoliaceae & Diervilla & lonicera & 23 & 1275 & 1 & 0 & 0 & 0 & 0 \\
\hline EUPRUG & Asteraceae & Eupatorium & rugosum & 16 & 700 & 0 & 0 & 0 & 0 & 1 \\
\hline TAROFF & Asteraceae & Taraxacum & officinale & 14 & 100 & 0 & 0 & 0 & 1 & 1 \\
\hline BETPAP & Betulaceae & Betula & papyrifera & 13 & 425 & 1 & 0 & 0 & 0 & 1 \\
\hline SAMSPP & Caprifoliaceae & Sambucus & spp. & 12 & 125 & 1 & 0 & 0 & 0 & 1 \\
\hline TSUCAN & Pinaceae & Tsuga & canadensis & 10 & 525 & 1 & 0 & 0 & 0 & 1 \\
\hline SCULAT & Lamiaceae & Scutellaria & lateriflora & 8 & 1475 & 0 & 0 & 0 & 0 & 0 \\
\hline MITNUD & Saxifragaceae & Mitella & nuda & 8 & 100 & 0 & 0 & 0 & 0 & 0 \\
\hline ERIPUL & Asteraceae & Erigeron & pulchellus ${ }^{\ddagger}$ & 7 & 50 & 0 & 0 & 0 & 0 & 1 \\
\hline PILPUM & Urticaceae & Pilea & pumila & 6 & 6300 & 0 & 0 & 1 & 0 & 0 \\
\hline EPIPAL & Onagraceae & Epilobium & palustre & 5 & 150 & 0 & 0 & 0 & 0 & 1 \\
\hline HYPSPP & Clusiaceae & Hypericum & spp. & 5 & 100 & 0 & 0 & 0 & 0 & 0 \\
\hline VIOSPP & Violaceae & Viola & spp. & 5 & 250 & 0 & 0 & 0 & 0 & 0 \\
\hline PLASPP & Plantaginaceae & Plantago & spp. & 5 & 100 & 0 & 0 & 0 & 1 & 1 \\
\hline ACERUB & Aceraceae & Acer & rubrum & 5 & 75 & 1 & 0 & 0 & 0 & 1 \\
\hline ANAMAR & Asteraceae & Anaphalis & margaritacea & 5 & 25 & 0 & 0 & 0 & 0 & 1 \\
\hline CHRAME & Saxifragaceae & Chrysosplenium & americanum & 4 & 1400 & 0 & 0 & 0 & 0 & 0 \\
\hline CARHIR & Brassicaceae & Cardamine & hirsuta & 4 & 375 & 0 & 0 & 1 & 1 & 0 \\
\hline CORSEM & Fumariaceae & Corydalis & sempervirens & 4 & 200 & 0 & 0 & 1 & 0 & 0 \\
\hline ACESAC & Aceraceae & Acer & saccharum & 4 & 100 & 1 & 0 & 0 & 0 & 1 \\
\hline POLCIL & Polygonaceae & Polygonum & cilinode & 4 & 50 & 0 & 0 & 0 & 0 & 1 \\
\hline \multirow[t]{19}{*}{ OXASTR } & Oxalidaceae & Oxalis & stricta ${ }^{\ddagger}$ & 4 & 50 & 0 & 0 & 0 & 0 & 0 \\
\hline & Polygonaceae & Polygonum & spp.* & 3 & 125 & 0 & 0 & 0 & - & - \\
\hline & Rosaceae & Potentilla & spp.* & 3 & 50 & 0 & 0 & 0 & - & 0 \\
\hline & Salicaceae & Salix & spp. & 3 & 50 & 1 & 0 & 0 & 0 & 1 \\
\hline & Cyperaceae & Carex & arctata & 2 & 225 & 0 & 1 & 0 & 0 & 0 \\
\hline & Rubiaceae & Galium & palustre & 2 & 175 & 0 & 0 & 0 & 0 & 0 \\
\hline & Scrophulariaceae & Gratiola & neglecta & 2 & 175 & 0 & 0 & 1 & 0 & 0 \\
\hline & Cyperaceae & Carex & platyphylla & 2 & 250 & 0 & 1 & 0 & 0 & 0 \\
\hline & Rosaceae & Prunus & pennsylvanicum & 2 & 25 & 1 & 0 & 0 & 0 & 1 \\
\hline & Cyperaceae & Carex & vulpinoidea or stipata & 1 & 4625 & 0 & 1 & 0 & 0 & 0 \\
\hline & Asteraceae & Chrysanthemum & leucanthemum & 1 & 525 & 0 & 0 & 0 & 1 & 1 \\
\hline & Cyperaceae & Carex & plantaginea & 1 & 150 & 0 & 1 & 0 & 0 & 0 \\
\hline & Cyperaceae & Carex & novae-angliae & 1 & 75 & 0 & 1 & 0 & 0 & 0 \\
\hline & Asteraceae & Erigeron & annuus ${ }^{\ddagger}$ & 1 & 50 & 0 & 0 & 1 & 0 & 1 \\
\hline & Clusiaceae & Hypericum & perforatum ${ }^{\ddagger}$ & 1 & 50 & 0 & 0 & 0 & 1 & 0 \\
\hline & Campanulacaeae & Lobelia & inflata & 1 & 50 & 0 & 0 & 1 & 0 & 0 \\
\hline & Lamiaceae & Scutellaria & sp. & 1 & 50 & 0 & 0 & 0 & 0 & 0 \\
\hline & Ranunculaceae & Aquilegia & canadensis & 1 & 25 & 0 & 0 & 0 & 0 & 0 \\
\hline & Chenopodiaceae & Chenopodium & album & 1 & 25 & 0 & 0 & 1 & 1 & 1 \\
\hline
\end{tabular}




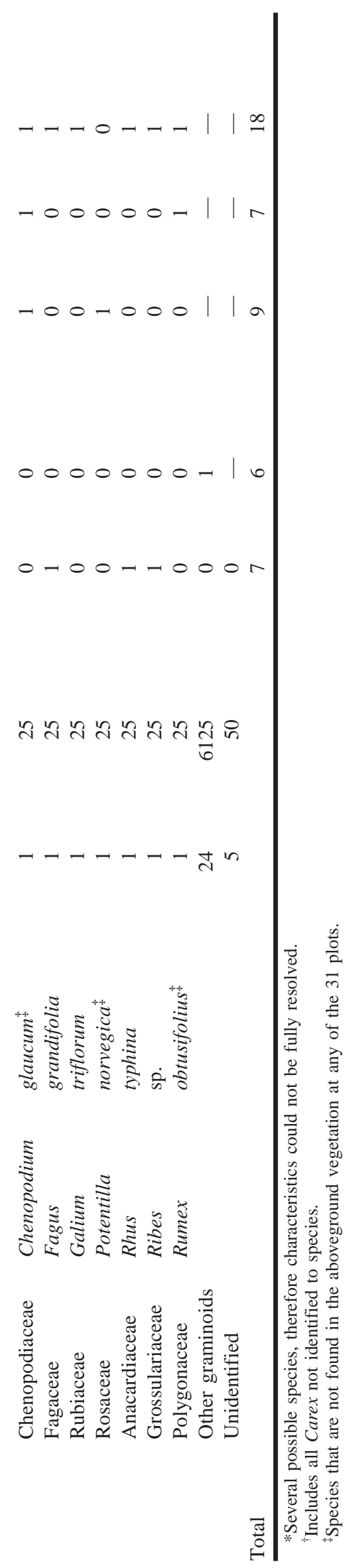

the Mantel correlation was relatively low $\left(r_{\mathrm{M}}=0.1\right)$. Although similarity between seed bank and vegetation was low at individual plots, $76 \%$ of seed bank species were found in the vegetation and, overall, there were relatively few nonforest species.

Much of the plot to plot variation in the seed bank can be explained by environmental variation among different habitats within this heterogeneous tract of forest. The first axis of the DCA (Fig. 1) explained 19\% of the variation in the seed bank data, and the first two axes explained a total of $29 \%$ of the variation. The contrasting patterns of species distribution in the seed bank from plot to plot were correlated with moisture regime, forest type, soil $\mathrm{NH}_{4}-\mathrm{N}$, soil $\mathrm{K}$, soil $\mathrm{Ca}$, and the number of aboveground species in the plot (Fig. 1). Woody species predominated in the seed bank of plots with richer soils, deeper litter, and more closed canopies. Herbaceous species predominated in the seed bank of plots with more open canopies, more mesic water regimes, and greater species richness in the aboveground vegetation.

\section{Properties of the seed bank and aboveground vegetation}

The seed bank included mostly herbaceous taxa, although two of the most common species were shrubs. Eighteen percent (9) of the 49 seed bank taxa were alien, and about half were classified as having long-distance dispersal (Table 2). Of the 186 species in the vegetation, about a third (54) were woody, including 28 tree species. Paired $t$-tests showed a significantly higher proportion of alien $(t=4.176, p<0.001$, $\mathrm{df}=30)$, annual $(t=3.229, p=0.003, \mathrm{df}=30)$, and woody $(t=4.292, p<0.001, \mathrm{df}=30)$ taxa in the seed bank than in the aboveground vegetation (Fig. 2).

The first axis of the PCA (Fig. 3) of the seed bank properties explained $39 \%$ of the variation in the data set, while the first two axes explained a total of $58 \%$ of the variation. Seed bank richness tended to increase with increased soil fertility (specifically, with increasing $\mathrm{NH}_{4}-\mathrm{N}, \mathrm{Ca}, \mathrm{Mg}$ ) and in more mesic sites, though it was not found to be correlated with either the number of species found in the vegetation, nor with seed density in the soil (Fig. 2). Significant Pearson correlations were found between seed bank richness and both $\log$ $\mathrm{NH}_{4}-\mathrm{N}(r=0.45, p=0.011)$ and $\mathrm{K}(r=0.38, p=0.037)$. The percentage of seed bank species having long-distance dispersal mechanisms increased with increased soil nutrients (Fig. 3). The highest seed densities and richness of both the seed bank and the vegetation were found in wetter habitats (Fig. 2; Table 1); two wet plots $(11,36)$ in particular had very high densities of graminoid species.

\section{Discussion}

Previous studies in temperate deciduous forests suggest that seed density in the seed bank declines after peaking in early- to mid-successional secondary forests, but then rises again as the canopy in mature forests begins to break up and pioneer species colonize canopy gaps (Pickett and McDonnell 1989; Thompson 1992; Peterson and Carson 1996). For example, the seed bank of Fagus-Acer-Betula forests in the mountains not far south of our study site have 287 seeds $\cdot \mathrm{m}^{-2} 5$ years after clear-cutting, 1903 seeds $\cdot \mathrm{m}^{-2}$ after 38 years, 1492 seeds. $\mathrm{m}^{-2}$ after 95 years, and 
Fig. 1. Species-environment biplot with arrows indicating increases in environmental variables and points indicating species scores in a detrended correspondence analysis of the seed bank data. Only species occurring in more than three plots were included in the ordination. (A) Species scores on axes 1 and 2;

$\star$, centroid of species scores. Species acronyms are given in Table 2. (B) Environmental variables: VEG, number of species in aboveground vegetation; MOISTURE, drier to wetter water regime; FOREST, xeric to mesic tree community type; CANDEN, density of forest canopy; SUBCAN, density of subcanopy; LITTER, leaf litter cover; ORG, percent of organic matter in soil; $\mathrm{NO}_{3}-\mathrm{N}$, nitrate in soil (ppm); $\mathrm{NH}_{4}-\mathrm{N}$, ammonium in soil (ppm); $\mathrm{PO}_{4}-\mathrm{P}$, phosphorous in soil (ppm); $\mathrm{Mg}$, magnesium in soil (mequiv. $100 \mathrm{~g}^{-1}$ ); Ca, calcium in soil (mequiv. $100 \mathrm{~g}^{-1}$ ); $\mathrm{K}$, potassium in soil (mequiv. $100 \mathrm{~g}^{-1}$ ).
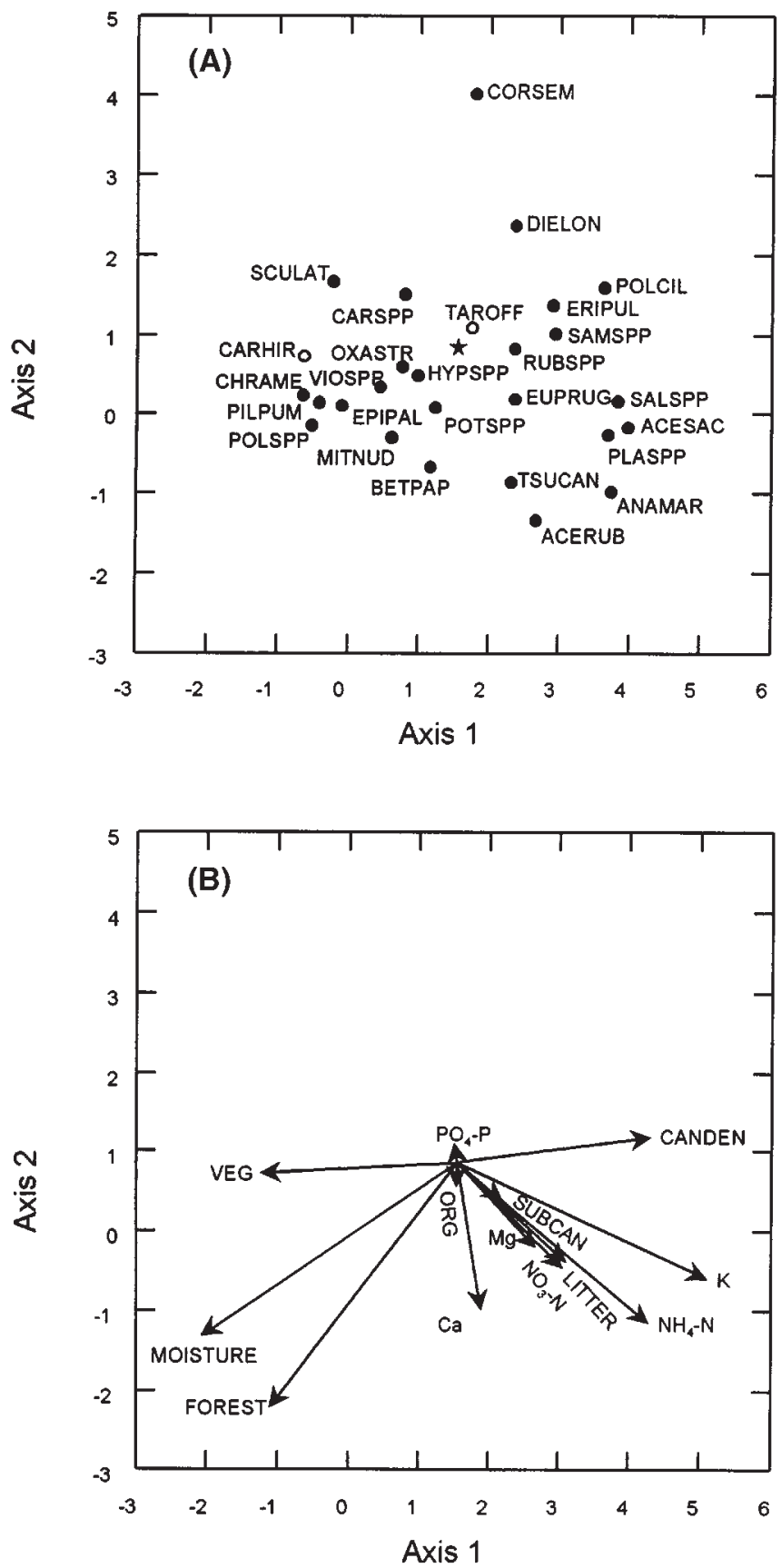

Fig. 2. Percentages of taxa in the seed bank and in the aboveground vegetation that $(i)$ belong to different life forms (W, woody; PD, perennial dicotyledon; M, monocot; AN, annual), (ii) are either alien (AL) or native $(\mathrm{N})$, and (iii) have either short (S) or long (L) distance dispersal.

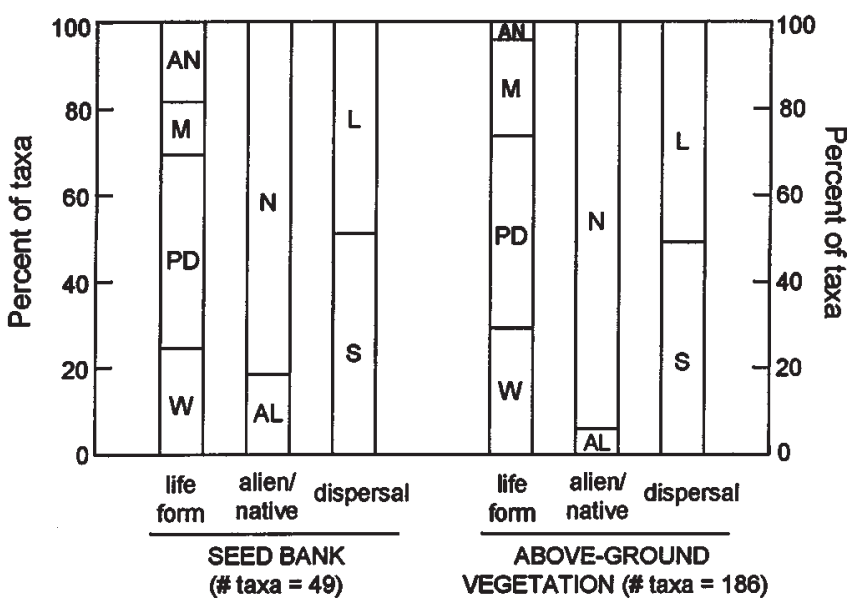

1633 seeds $\cdot \mathrm{m}^{-2}$ in a primary forest over 200 years old (Graber and Thompson 1978). Published reports for seed banks in secondary temperate deciduous forests are usually in the range 1000-5000 seeds $\cdot \mathrm{m}^{-2}$ (Moore and Wein 1977; Graber and Thompson 1978; Staaf et al. 1987; Matlack and Good 1990; Kjellsson 1992; Schiffman and Johnson 1992; Eriksson 1995; Smallidge and Leopold 1995; JankowskaBłaszczuk et al. 1998). Jankowska-Błaszczuk and Grubb (1997) summarize studies of the seed bank in a variety of old-growth north temperate forests that report seed densities ranging from 218 to 2514 seeds $\cdot \mathrm{m}^{-2}$. The median seed bank density in the old-growth forest at Mont St. Hilaire (1218 seeds $\cdot \mathrm{m}^{-2}$ ) falls nicely within this range, but the seed bank density from place to place at Mont St. Hilaire varies greatly, ranging from as low as 475 to as high as 16700 seeds $\cdot \mathrm{m}^{-2}$. We suspect that there may be more variation in seed bank density among habitats within a tract of temperate forest than among forests of different ages and disturbance histories.

There appears to be little compelling evidence for consistent variation in the richness of seed banks as a function of time since disturbance in temperate deciduous forests. The successional sequence of Fagus-Acer-Betula forests studied by Graber and Thompson (1978) had only between 6 and 9 species. Olmsted and Curtis (1947) report 10 species in the seed bank of a 50-year-old Fagus-Betula-Acer forest (215 seeds $\cdot \mathrm{m}^{-2}$ ), and 12 in a 110-year-old forest (990 seeds $\left.\cdot \mathrm{m}^{-2}\right)$. Previous studies have reported $8-51$ species in the seed bank of mature, temperate deciduous forests, with most forests at the lower end of this range (Moore and Wein 1977; Graber and Thompson 1978; Staaf et al. 1987; Matlack and Good 1990; Kjellsson 1992; Schiffman and Johnson 1992; Eriksson 1995; Smallidge and Leopold 1995; Jankowska-Błaszczuk and Grubb 1997; JankowskaBłaszczuk et al. 1998). We found at least 38 different forest taxa in the seed bank at Mont St. Hilaire, and another 11 weedy species from the surrounding, nonforested landscape. Our individual $1250-\mathrm{m}^{2}$ plots, which were not intensively 
sampled, had 5-14 native, forest taxa in the seed bank (Table 1), a level of diversity comparable to many reports for entire forests. We conclude that the seed bank at Mont St. Hilaire as a whole is rich in species compared with that in most other temperate forests, and certainly richer than the seed banks reported in earlier stages of forest succession.

We suspect that two factors contribute to this high species diversity in the seed bank at Mont St. Hilaire: (i) the diversity of habitats within this large tract of old-growth forest (Pickett and McDonnell 1989; Beatty 1991; Ashton et al. 1998) and (ii) the natural disturbance regime in this high latitude deciduous forest (Pickett and McDonnell 1989; Thompson 1992; Jankowska-Błaszczuk and Grubb 1997). The composition of the seed bank clearly varies with environmental conditions, and the range of environmental regimes represented at Mont St. Hilaire is substantial (Maycock 1961; Enright and Lewis 1985). This spatial variation in the environment is further augmented by temporal variation induced by the natural disturbance regime at this site. In addition to the normal dynamic of gap formation expected in an old-growth deciduous forest, the forest canopy at Mont St. Hilaire frequently is disrupted over its entire extent by ice storms. Ice storms prune weakened branches from the canopy and, in severe cases, can destroy even healthy tree crowns, although the nature and extent of damage varies from one tree species to another (Hooper 1999). Minor ice storms occur virtually every year at Mont St. Hilaire, but major storms have a return time on the order of 20 years (Melancon and Lechowicz 1987; Hooper 1999). The canopy of this old-growth forest is thus kept fairly open and many somewhat shade-intolerant forest herbs persist at the site. This disturbance regime may account for the high frequency in the seed bank of species of Rubus and Carex, which generally thrive in canopy openings (Hughes and Fahey 1991). Contrary to expectations (Thompson 1978; Pickett and McDonnell 1989; Kjellsson 1992; Schiffman and Johnson 1992), the high frequency of shade-intolerant herbs in the seed bank at Mont St. Hilaire does not include a high proportion of colonizing, early successional species. As in a number of Polish studies in extensive old-growth forests (Piroznikov 1983; Jankowska-Błaszczuk et al. 1998), the seed bank at Mont St. Hilaire is rich in both shade-tolerant and shade-intolerant forest species.

The strong presence of Carex in the seed bank and in the aboveground vegetation at Mont St. Hilaire is noteworthy. There are over 50 species of Carex in the aboveground vegetation in the forest at Mont St. Hilaire, and Carex is the single largest component of the seed bank. Seeds of Carex are often reported in the seed banks of temperate forests and other ecosystems, and are frequently among the most abundant species (Piroznikov 1983; Kramer and Johnson 1987; Fyles 1989; Pickett and McDonnell 1989; Matlack and Good 1990; Hughes and Fahey 1991; Kjellsson 1992; Warr et al. 1994; Eriksson 1995; Smallidge and Leopold 1995). Staaf et al. (1992) suggest that the limited dispersal of sedges may make them especially dependent on seed banks, while Kjellsson (1992) noted that there was considerable variation over space for seed numbers of sedge, grass, and rush species. The ubiquity of Carex seed banks combined with the large number of species and the diversity of niches exploited
Fig. 3. Biplot of principal components analysis of seed bank properties and properties of vegetation in each study plot, with arrows indicating increases in environmental variables; $\star$, centroid of scores. (A) Scores of seed bank and vegetation properties on PCA axes 1 and 2: TOTSP, number of seed bank species; TOTSD, total number of seeds; WDYSP, percent of woody species in seed bank; WDYSD, percent of total seeds represented by woody species; DISPSP, percent of seed bank species with longdistance dispersal; DISPSD, percent of total seeds represented by species with long-distance dispersal; ANNSP, percent of annual species in seed bank; ANNSD, percent of total seeds represented by annual species; DISPVEG, percent of species in aboveground vegetation with long-distance dispersal; ANNVEG, percent of annual species in aboveground vegetation. (B) Environmental variables as in Fig. 1. Nitrate-N and phosphate had too little correlation with the seed bank properties to show up in the figure.
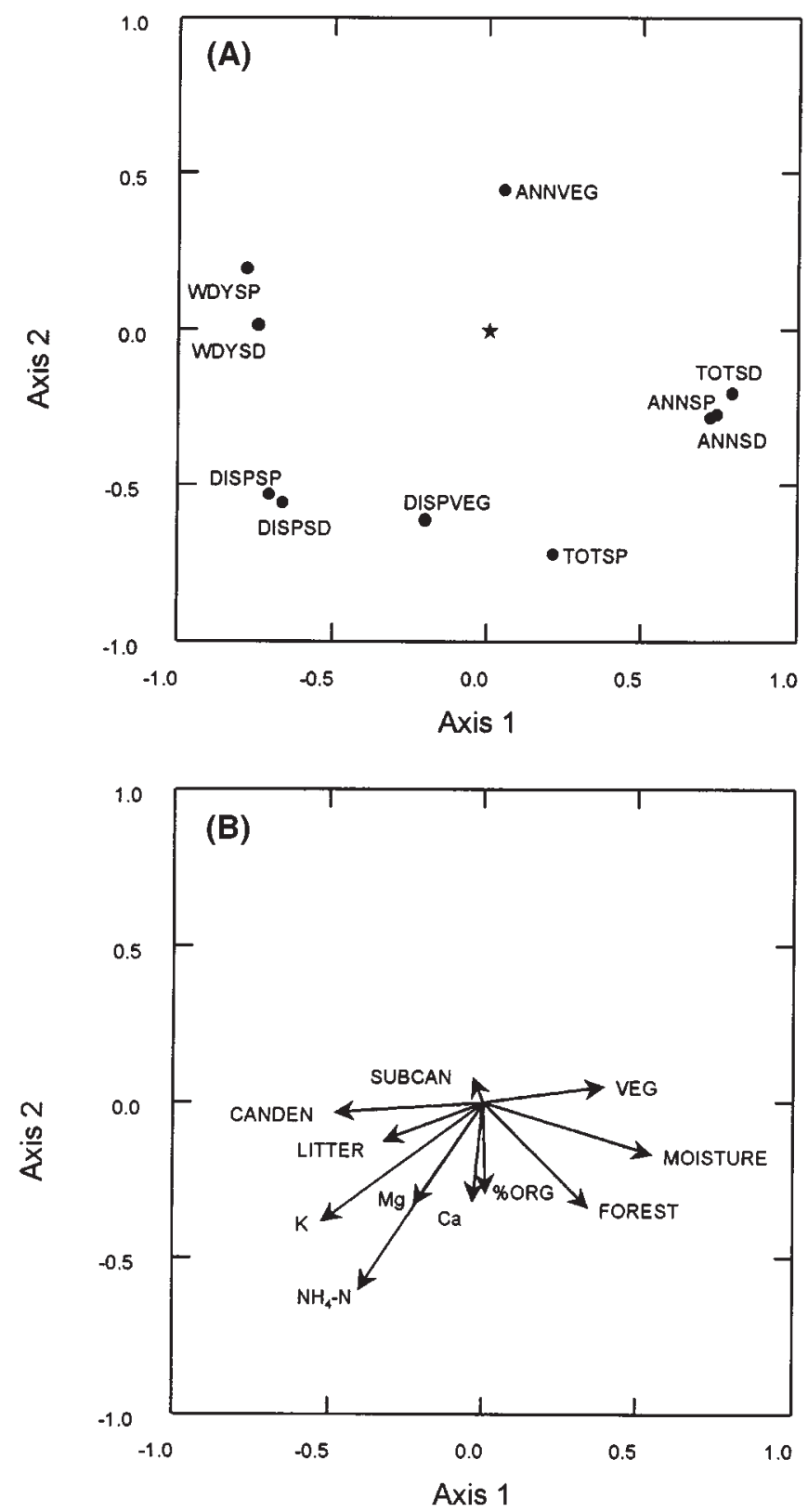
by these species suggest that seed dynamics in Carex species merit more detailed study.

Another part of the interesting floral diversity on Mont St. Hilaire is the group of spring ephemerals - a group of forest herbs that is apparently absent from the seed bank. Other studies have also noted a lack of persistent seed banking in vernal species (Brown and Oosterhuis 1981; Schiffman and Johnson 1992). It has been suggested that seed banking as a strategy is not as important for these species because many possess alternative modes of propagation including stolons, corms, and bulbs (Pickett and McDonnell 1989). Vernal species are already taking advantage of times of high light and nutrient availability in the spring before the trees leaf out (Rogers 1982); they would gain little or nothing by seed banking to exploit disturbances leading to canopy opening. Beatty (1984) reported that two vernal species, Claytonia caroliniana and Erythronium americanum, had higher importance values on undisturbed microsites than on treefall mounds or pits, suggesting that recruitment from seed banks on disturbed sites is not an important method of propagation. Since many vernal species are ant dispersed (Handel and Beattie 1990) and therefore have very patchy seed distribution, it also is possible that the sampling methods typical in seed bank studies fail to detect their buried seed.

Forest seed banks are generally considered to contain little tree seed (Marquis 1975; Graber and Thompson 1978; Schiffman and Johnson 1992). To some degree this also may be an artifact of limited sampling intensity. Piroznikov (1983) found that while the number of seeds for herbaceous species in the seed bank remained relatively constant in different years, the numbers for woody species fluctuated widely. Factors contributing to this variability include germination dynamics, seed rain intensity, dispersion patterns, and seed mortality (Marquis 1975; Thompson and Grime 1979; Thompson 1986; Mladenoff 1990; Houle 1994). On the other hand, Froberg and Eriksson (1997) discuss the greater capability of large seeds to germinate and establish from under leaf litter, which makes them less dependent on seed banking until a disturbance to establish. Many shade-tolerant forest trees also maintain seedling banks rather than seed banks. It is noteworthy that the tree species found in the seed bank at Mont St. Hilaire and other mature forest sites (Moore and Wein 1977; Piroznikov 1983; Fyles 1989; Kjellsson 1992; Peterson and Pickett 1995) are often shadeintolerant taxa such as Betula and Populus that produce seed every year and have potentially long-range, wind dispersal. At Mont St. Hilaire, the seed of wind-dispersed and shadetolerant Tsuga canadensis is also quite frequent. Thus while the seed bank at Mont St. Hilaire has a fairly low number of tree seeds as expected, both shade-tolerant and shadeintolerant tree species are well represented and are likely to play a role in normal cycles of regeneration in this forest.

Peterson and Carson (1996) argue that large, undisturbed forests are not expected to have high seed bank densities of pioneers and weeds, unless the disturbance regime has a return time less than the total longevity of plants and seeds. However, small or remnant old-growth stands, surrounded by agricultural and disturbed areas are more likely to have regular inputs of these weedy seeds (Peterson and Carson 1996). Because Mont St. Hilaire is surrounded by farms and suburban housing and has trail access, species typical of ruderal and agricultural habitats might be expected to form a seed bank without mature plants being in the forest now or in the distant past. In fact, the overall presence of alien species in the seed bank at Mont St. Hilaire is quite low. Only one study plot has as many as three alien species in the seed bank and a quarter of the plots have none. The density of alien seeds is usually one or two orders of magnitude less than that of native species. Taraxacum officinale is frequent (14 sites), but this is not surprising since it is wind dispersed and occurs frequently on the developed lands surrounding Mont St. Hilaire. Plantago species are frequent along trails at Mont St. Hilaire and could easily be dispersed by animals to the five sites where they are in the seed bank. At least some of these seedlings are Plantago rugelii, which is native to forests in North America and is known to have seed longevity in excess of 20 years (Hawthorn 1974). Alien species that are infrequent in the seed bank such as Chrysanthemum leucanthemum, Rumex obtusifolius, Chenopodium album, Chenopodium glaucum, Cardamine hirsuta, and Hypericum perforatum are all infrequent in the forest seed bank. With the exception of Taraxacum officinale, alien species from the developed landscape around this fragment of old-growth forest do not seem very able to colonize the forest seed bank.

In summary, the seed bank of this old-growth forest is dominated by forest species, not by weedy aliens associated with adjacent disturbed landscapes. In contrast with other studies, the seed bank of this old-growth forest was found to be fairly diverse - a circumstance due more to the physiographic, habitat, and floristic diversity at Mont St. Hilaire than to the modest inputs of seed from the adjacent modified landscape. We suggest that the seed banks of old-growth forests may have more similarity to the aboveground vegetation than is typical in secondary forests developed after harvests or other human disturbance. What we find in the seed bank at Mont St. Hilaire appears to be primarily the result of seed dispersal and dormancy characteristics of native species growing naturally in this tract of old-growth forest.

\section{Acknowledgments}

This work was supported by a grant from the Fonds pour la formation de cherceurs et l'aide à la recherche (FCAR, Québec) to G. Bell, P. Dutilleul, M. Lechowicz, and M. Waterway. We thank Julia Baum, Stéphanie Duguay, Katrina Nolan, and Oana Spinu for assistance in characterizing the study plots and collecting soil samples, and Ellen Macdonald for facilitating the soil analyses.

\section{References}

Ashton, P.M.S., Harris, P.G., and Thadani, R. 1998. Soil seed bank dynamics in relation to topographic position of a mixeddeciduous forest in southern New England, U.S.A. For. Ecol. Manage. 111: 15-22.

Baskin, C.C., and Baskin, J.M. 1998. Seeds - Ecology, biogeography, and evolution of dormancy and germination. Academic Press, San Diego, Calif.

Beatty, S.W. 1984. Influence of microtopography and canopy species on spatial patterns of forest understory plants. Ecology, 65: 1406-1419. 
Beatty, S.W. 1991. Colonization dynamics in a mosaic landscape: the buried seed pool. J. Biogeogr. 18: 553-563.

Bell, G., Lechowicz, M.J., and Waterway, M.J. 2000. Environmental heterogeneity and species diversity of forest sedges. J. Ecol. 88: 67-87.

Bray, R.H., and Kurtz, T. 1945. Determination of total, organic, and available forms of phosphorus in soils. Soil Sci. 59: 39-45.

Brayshaw, T.C. 1959. Tree seedlings of Eastern Canada. Department of Northern Affairs and Natural Resources, Forestry Branch Bulletin no. 122, Queens Printer, Ottawa.

Brown, A.H.F., and Oosterhuis, L. 1981. The role of buried seed in coppicewoods. Biol. Conserv. 21: 19-38.

Brown, D. 1992. Estimating the composition of a forest seed bank: a comparison of the seed extraction and seedling emergence methods. Can. J. Bot. 70: 1603-1612.

Cavers, P.B. 1983. Seed demography. Can. J. Bot. 61: 3578-3590.

Chapman, H.D. 1965. Cation exchange capacity. Agronomy No. 9. In Methods of soil analysis, Part 2. Edited by C.A. Black. American Society of Agronomy, Madison, Wisc. pp. 891-901.

Cook, B.D. 1971. Tree-age distribution in a northern hardwood forest. Unpublished M.Sc. thesis, Department of Geography, McGill University, Montréal, Québec.

Enright, N.J., and Lewis, J.E. 1985. Aspect-related vegetation patterns and climate at Mont St. Hilaire, Quebec. Can. Geogr. 29: 249-256.

Eriksson, O. 1995. Seedling recruitment in deciduous forest herbs: the effects of litter, soil chemistry and seed bank. Flora (Jena), 190: $65-70$.

Feininger, T., and Goodacre, A.K. 1995. The eight classical Monteregian Hills at depth and the mechanisms of their intrusion. Can. J. Earth Sci. 32: 1350-1364.

Fenner, M. 1985. Seed ecology. Chapman and Hall, London.

Froberg, H., and Eriksson, O. 1997. Local colonization and extinction of field layer plants in a deciduous forest and their dependence upon life history features. J. Veg. Sci. 8: 395-400.

Fyles, J.W. 1989 Seed bank populations in upland coniferous forests in central Alberta. Can. J. Bot. 67: 274-278.

Gleason, H.A., and Cronquist, A. 1991. Manual of vascular plants of northeastern United States and adjacent Canada. 2nd ed. The New York Botanical Garden, Bronx, N.Y.

Graber, R.E. and Thompson, D.F. 1978. Seeds in the organic layers and soil of four beech-birch-maple stands. U.S. For. Serv. Res. Pap. NE-401.

Handel, S.N., and Beattie, A.J. 1990. Seed dispersal by ants. Sci. Am. (August): 76-81.

Handel, S.N., Fisch, S.B., and Schatz, G.E. 1981. Ants disperse a majority of herbs in a mesic forest community in New York State. Bull. Torrey Bot. Club. 108: 430-437.

Hawthorn, W.R. 1974. The biology of Canadian weeds. 4. Plantago major and P. rugelii. Can. J. Plant Sci. 54: 383-396.

Hooper, M. 1999. Impacts of a catastrophic ice storm on an oldgrowth, hardwood forest. Unpublished M.Sc thesis, Department of Biology, McGill University, Montreal, Que.

Houle, G. 1994. Spatiotemporal patterns in the components of regeneration of four sympatric tree species - Acer rubrum, A. saccharum, Betula alleghaniensis and Fagus grandifolia. J. Ecol. 82: 39-53.

Hughes, J.W., and Fahey, T.J. 1991. Colonization dynamics of herbs and shrubs in a disturbed northern hardwood forest. J. Ecol. 79: 605-616.

Jankowska-Błaszczuk, M., and Grubb, P.J. 1997. Soil seed banks in primary and secondary deciduous forest in Białowieüa, Poland. Seed Sci. Res. 7: 281-292.
Jankowska-Błaszczuk, M., Kwiatkowska, A.J., Panufnik, D., and Tanner, E. 1998. The size and diversity of the soil seed banks and the light requirements of the species in sunny and shady natural communities of the Białowieüa Primeval Forest. Plant Ecol. 136: 105-118.

Jongman, R.H.G., ter Braak, C.J.F., and Van Tongeren, O.F.R. 1995. Data analysis in community and landscape ecology. Cambridge University Press, Cambridge, U.K.

Kalra, Y.P., and Maynard, D.G. 1991. Methods manual for forest soil and plant analysis. Can. For. Serv. North. For. Res. Cent. Inf. Rep. NOR-X-319.

Kellman, M. 1970. The viable seed content of some forest soils in coastal British Columbia. Can. J. Bot. 48: 1383-1385.

Kjellsson, G. 1992. Seed banks in Danish deciduous forest: species composition, seed influx and distribution pattern in soil. Ecography, 15: 86-100.

Kramer, N.B., and Johnson, F.D. 1987. Mature forest seed banks of three habitat types in central Idaho. Can. J. Bot. 65: 1961-1966.

Lavoie, G. 1992. Plantes vasculaires susceptibles d'être désignées menacées ou vulnérables au Québec. Direction de la conservation et du patrimoine écologique, Ministère de l'environnement du Québec, Québec.

Leck, M.A., Parker, V.T., and Simpson, R.L. 1989. Ecology of Soil Seed Banks. Academic Press, San Diego, Calif.

Legendre, P., and Legendre, L. 1998. Numerical ecology. 2nd ed. Elsevier Science B.V., Amsterdam, The Netherlands.

Mantel, N. 1967. The detection of disease and a generalized regression approach. Cancer Res. 27: 209-220.

Manly, B.F.J. 1997. RT: A program for randomization testing. Center for Applications of Statistics and Mathematics, University of Otago, New Zealand.

Marie-Victorin, frère, E.C. 1913. Aperçus sur la flore de la montagne de Sainte-Hilaire. Bull. Soc. Géogr. Québec, 7: 163-168.

Marie-Victorin, frère, E.C. 1995. Flore Laurentienne. 3rd ed. Updated and annotated by L. Brouillet and I. Goulet. Presses de l'Université de Montreal, Montreal, Que.

Marquis, D.A. 1975. Seed storage and germination under northern hardwood forests. Can. J. For. Res. 5: 478-484.

Martin, A.C., Zim, H.S., and Nelson, A.L. 1951. American wildlife and plants - A guide to wildlife food habits: the use of trees, shrubs, weeds, and herbs by birds and mammals of the United States. McGraw-Hill Book Company, New York.

Matlack, G.R., and Good, R.E. 1990. Spatial heterogeneity in the soil seed bank of a mature Coastal Plain forest. Bull. Torrey Bot. Club. 1172: 143-152.

Maycock, P.F. 1961. Botanical studies on Mont St. Hilaire, Rouville County, Quebec: general description of the area and a floristic survey. Can. J. Bot. 39: 1293-1325.

Melancon, S., and Lechowicz, M.J. 1987. Differences in the damage caused by glaze ice on codominant Acer saccharum and Fagus grandifolia. Can. J. Bot. 65: 1157-1159.

Mladenoff, D.J. 1990. The relationship of the soil seed bank and understory vegetation in old-growth northern hardwood - hemlock treefall gaps. Can. J. Bot. 68: 2714-2721.

Moore, J.M., and Wein, R.W. 1977. Viable seed populations by soil depth and potential site recolonization after disturbance. Can. J. Bot. 55: 2408-2412.

Nakagoshi, N. 1985. Buried viable seeds in temperate forests. In The population structure of vegetation. Edited by J. White. Junk, Dordrecht, The Netherlands. pp. 551-570.

Økland, R.H. 1996. Are ordination and constrained ordination alternative or complementary strategies in general ecological studies? J. Veg. Sci. 7: 289-292. 
Olmsted, N.W., and Curtis, J.D. 1947. Seeds of the forest floor. Ecology, 28: 49-52.

Peterson, C.J., and Carson, W.P. 1996. Generalizing forest regeneration models: the dependence of propagule availability on disturbance history and stand size. Can. J. For. Res. 26: 45-52.

Peterson, C.J., and Pickett, S.T.A. 1995. Forest reorganization: a case study in an old-growth forest catastrophic blowdown. Ecology, 763: 763-774.

Pickett, S.T.A., and McDonnell, M.J. 1989. Seed bank dynamics in temperate deciduous forests. In Ecology of soil seed banks. Edited by M.A. Leck, V.T. Parker, and R.L. Simpson. Academic Press, San Diego, Calif. pp. 123-147.

Piroznikov, E. 1983. Seed bank in the soil of stabilized ecosystem of a deciduous forest Tilio-Carpinetum in the Bialowieza National Park. Ekol. Pol. 311: 145-172.

Poole, W.H., Sanford, B.V., and Hacquebard, P.A. 1976. Geology of southeastern Canada. In Geology and economic minerals of Canada. Edited by R.J.W. Douglas. Department of Energy, Mines and Resources, Ottawa, Ont. pp. 229-304.

Pratt, D.W., Black, R.A., and Zamora, B.A. 1984. Buried viable seed in a ponderosa pine community. Can. J. Bot. 62: 44-52.

Raymond, M. 1950. Esquisse phytogéographique du Québec. Mémoires du Jardin Botanique de Montréal, 5: 1-147.

Rees, M. 1996. Evolutionary ecology of seed dormancy and seed size. Philos. Trans. R. Soc. London, B Biol. Ser. 351: 1299-1308.

Rogers, R.S. 1982. Early spring herb communities in mesophytic forests of the Great Lakes region. Ecology, 63: 1050-1063.

Schiffman, P.M., and Johnson, W.C. 1992. Sparse buried seed bank in a southern Appalachian oak forest: implications for succession. Am. Midl. Nat. 127: 258-267.

Smallidge, P.J., and Leopold, D.J. 1995. Watershed liming and pit and mound topography effects on seed banks in the Adirondacks, New York, U.S.A. For. Ecol. Manage. 72: 273-285.

Staaf, H., Jonsson, M., and Olsen, L.-G. 1987. Buried germinative seeds in mature beech forests with different herbaceous vegetation and soil types. Holarct. Ecol. 10: 268-277.

ter Braak, C.J.F., and Smilauer, P. 1998. CANOCO reference manual and user's guide to CANOCO for Windows: Software for canonical community ordination (version 4). Microcomputer Power, Ithaca, N.Y.

Thompson, K. 1978. The occurrence of buried viable seeds in relation to environmental gradients. J. Biogeogr. 5: 425-430.

Thompson, K. 1986. Small-scale heterogeneity in the seed bank of an acidic grassland. J. Ecol. 74: 733-738.

Thompson, K. 1992. The functional ecology of seed banks. In The ecology of regeneration in plant communities. Edited by $\mathrm{M}$. Fenner. CAB International, London, U.K. pp. 231-258.

Thompson, K., Band, S.R., and Hodgson, J.G. 1993. Seed size and shape predict persistence in soil. Funct. Ecol. 7: 236-241.

Thompson, K., Bakker, J.P., and Bekker, R.M. 1997. The soil seed banks of North West Europe: Methodology, density and longevity. Cambridge University Press, Cambridge, U.K.

Warr, S.J., Kent, M., and Thompson, K. 1994. Seed bank composition and variability in five woodlands in south-west England. J. Biogeogr. 21: 151-168. 